\title{
HAZARDOUS WASTE HANDLING AT AIRPORT
}

\author{
Wynd Rizaldy ${ }^{1}$, Devi Marlita ${ }^{2}$, Agus Setiawan ${ }^{3}$, Okin Purba ${ }^{4}$ \\ 1. STMT Trisakti, 2. STMT Trisakti, 3. STMT Trisakti, 4. STMT Trisakti \\ $\triangle$ corresponding author: wyndrizaldy@gmail.com
}

\begin{abstract}
The paper objective is to identify and analyze the matter of handling waste and chemical at the Airport (Soekarno-Hatta Airport). This Paper review and analyze the Ministerial Decree of Communication of The Republic Indonesia Number: PM 54 year 2017 about the waste and chemical management of Aircraft and Airport Operation and the previous Literature. This paper method is descriptive-explorative using a quantitative qualitative data source from Airport Operator and Ministry concerned, public policy analysis and Forum Group Discussion (FGD). The results of this paper to encourage party to find the correct steps in managing waste and chemical at the airport in Indonesia and formulate it become one fix and applicable technical instruction for better handling of waste and chemical starting from Soekarno-Hatta Airport as a pilot project of waste handling implementation in the near future. Benefit of the stake holder in airport to have the Standard Operating Procedure (SOP) as a assisting tool for implementing the integrated waste management while waiting the technical instruction from The Airport regulator.

Keywords: Airport; Waste chemical Management; SOP
\end{abstract}

\section{Introduction}

The important of this paper to analyze the handling waste and chemical at airport cause the "Airports are typically associated with detrimental environmental effects. They are seen to have substantial influences in terms of air pollution, energy consumption, noise pollution, waste production and hydrological damage" (Pitt, Brown, \& Smith, 2002). "Passenger numbers increase in the long term, the waste stream will also increase" (Pitt et al., 2002). "Population growth after the crisis of 1998, was accompanied by a very encouraging economic growthreaching $6.3 \%$ during 2012. Accordingly, the development of the aviation industry continues to increase rapidly" (Juliater Simarmata, Charles, \& Rizaldy, 2014). "This is a serious problem as airports already produce waste levels equivalent to small cities. The hierarchy as: "reduction, reuse, recycling, recovery, treatment and disposal", with desirability decreasing down the hierarchy" (Seadon, 2006). If all the parties involved in the managing of wastes taking their part in achieving sustainable waste management, it will not only 
able to improve current condition for the economic, social or environmental aspects, it can also reduce the issues of settling the gradually increasing solid wastes by having a better technology in the sustainable waste management (Sin, Chen, Long, Goh, \& Hwang, 2013). Waste handling become a big issue wherever you are, especially if the waste exist in public area like in Airport and may affect the whole service and health of environment. The International Airport of Soekarno-Hatta (IATA code CGK, ICAO: WIII) is a main airport which serve flight of Jakarta City, Indonesia. Currently there are 4 main buildings as follow Terminal 1, 2, 3 and Cargo Terminal. On the newest "Masterplan" stated that The Airport has a theme of "Modern Airport with Traditional touch", and for this mega project PT Angkasa Pura II as operator construct the the Airport become integrated building. A lot of activity will create waste during the development and movement of people around this area. Therefor in this condition the Operator with the stake holder need to ensure the professional management in handling it, including the Waste and chemical that may affected to the users, as well as the environment. Coordination among the institutions and stake holders when supporting the aircraft and airport operation based on the valid regulation. "Timely delivery of goods is very dependent on the condition of public infrastructure provided by the government of a country. As a result, the demands of efficiency in higher logistics activities, including the level of security quality, safety and service" (S, 2016) 2 elements of waste management by reducing it with $3 R$ concept Reduce-Recycle-Reuse, and Handling it with sorting out, collect, carry, and process it tills the end process which result positive affect. Based on Master plan of the build airport, the government prepared the supporting infrastructure of this waste management The waste management to manage the aqueous waste need integrated infrastructure, while to manage solid waste, the airport use incinerator to dispose them thermally. From the matter above the authority or the operator need to analyze the specific issue against the public policy and socialize the Ministerial decree as the sub regulation of the Indonesian laws of the legal standing in managing the 
activity of waste management. The Minister standardize the decree based on the reference of concerning minister, either transportation, environment and Health to find the solution to waste \& chemical management. Limit The scope review only on one Airport in Jakarta as the capital city of Indonesia as well as main gateway.

\section{Method}

\section{Participant}

The participants of the decree socialization are from both private and government sectors in Indonesia. There are Four categories of the professions and expert who participate and share the knowledge, namely Ministry of Environment and Forestry (KLH), site engineer of Airport Operator, assistant environmental control officer and contractors.

\section{Apparatus}

This paper based on study of literature review and collection of secondary data from Airport Operator and from the experts' sharing of the waste management from each side point of view at the socialization continue with forum group discussion (FGD).

\section{Procedures}

Through the extensive literature review, we identified the overview of the current waste management. Besides, through the extensive literature review in this paper, it provides a solid background of challenges in developing sustainable waste management. In addition, we conduct the exploratory interviews from six industry practitioners. The aim of conducting exploratory interview for this paper is to determine the readily of collection data via extensive literature review and to know that the Airport and stake holders face the current challenges..

\section{Discussion and Results}

The public policy based on the waste management philosophy till become the sustainable development, and need to adjust the policy with the Indonesian Law (UU) no. 18/year 2008. from one-way economy as end of 
pipe solution to circular economy, that is the philosophy of waste management towards sustainable development. On the law stated the Producer or factory which produce to consumer, also has potential to produce or remain the waste with three category such as waste aqueous, solid, and gases. The Process of these wastes by $3 \mathrm{R}$ ways, and handling it by sorting, collecting, transporting, processing, and end processing at final disposal place (TPA) or temporary disposal place (TPST) to become Circular Economy. So from the execution of the Philosophy and the Indonesian Law (UU) number 18/2008, later on Government Law (PP) number $81 / 2018$, if those are synergies will become a formation toward the policy or the "new paradigm of waste management".

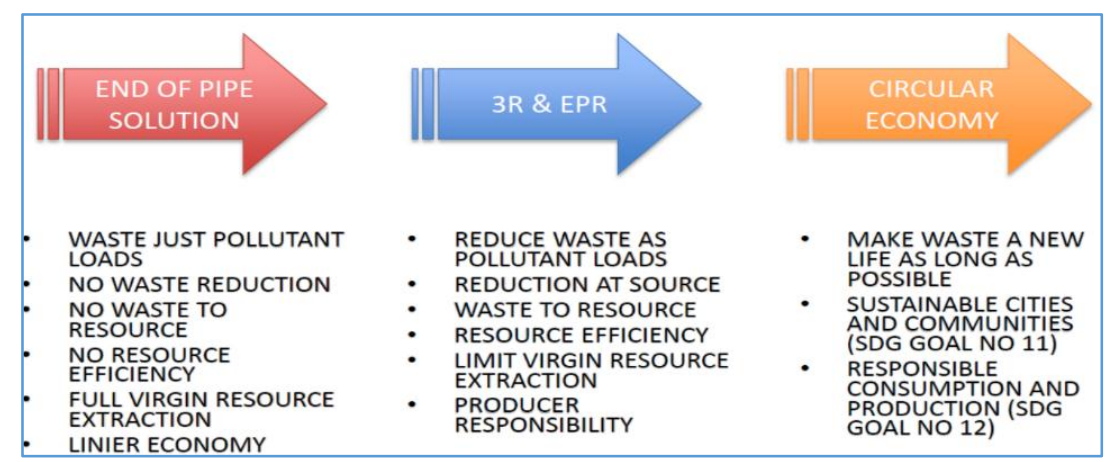

Figure 1. New Paradigm of Waste Management based on UU18/2008

The content of the Law has adopted some international regulation, such as ISO 14001 and GHS, and once countries have consistent and appropriate information on the chemicals they import or produce in their own countries, They will establish a comprehensive manner for the infrastructure to control chemical exposures and protect people and the environment. $1^{\text {st }}$ analysis improves on existing studies of ISO 14001 efficacy by expanding the sample size and by controlling for potential endogeneity problems between facilities'. $2^{\text {nd }}$ analysis suggests that ISO 14001-certified facilities have better environmental performance they reduced their pollution emissions faster compared to non-participants. decision to join ISO 14001 and their environmental performance, and $3^{\text {rd }}$ suggests that even a relatively "weak sword" program such as ISO 14001, whose enforcement mechanism is based on third-party audits without public 
disclosure of audit information, can mitigate shirking in voluntary programs (Potoski \& Prakash, 2005). "In this study we show that ISO 14001 has the potential, when used under the right circumstances, to improve sustainability across the supply chain. In other words, it is a tool for sustainability" (Curkovic \& Sroufe, 2011). "At this level, tools such as Life-Cycle Assessment (LCA) can be used to support the implementation of sustainability goals, and ISO 14001 could be used to guide the process over the long term" (MacDonald, 2005). Given the reality of the extensive global trade in chemicals, and the need to develop national programs to ensure their safe use, transport and disposal, it was recognized that an internationally-harmonized approach to classification and labelling would provide the foundation for such programs (United Nations, 2015). In general, it is very challenging to assess whether a particular country has successfully implemented GHS as the GHS covers all chemicals. The absence of international or national tools has impeded the justification for measuring implementation of GHS, as it is indeed difficult to measure “implementation” of GHS (Ta, Jonai, Mokhtar, \& Peterson, 2009). From the perspective of government policy, the progress in the management of hazardous substances and waste resulted from: The intensification of enforcement of the Environmental Quality Act of 1974; The preparation of a code of practice for hazardous waste management; The institution of environmentally sound management of toxic chemicals, and The enhancement of chemical safety, especially relating to banned and severely restricted chemical (Ujang, 2000). In field also doesn't have special facility to manage hazardous waste (B3) that can be used by people, there is no officer in charge and no availability of hazardous waste processing facility in public level can cause the hazardous waste mixed with domestic waste, the entry for hazardous waste inside TPA can create heavier pollution (Setiyono, 2001). The values of Health and Safety Culture in the cargo handling at Soekarno Hatta Airport are above the score / index average 5.0 which means that in general the whole individual in this section posses the moderate level of Health and Safety values (Kania, 2016). With 
the national policies above, so the Indonesia government also determined the performance target of waste management till year 2025, and projected the formulation will end up with composting $70 \%$ waste processing and the rest $30 \%$ is waste reducing itself with each sub. The indicator of performance achievement or target which is set up to have the guaranty quality performance result, where the 6 indicators of performance. The indicators come from 2 types of waste management are $1^{\text {st }}$ Type is Waste Reducing and $2^{\text {nd }}$ Type is Waste Processing.

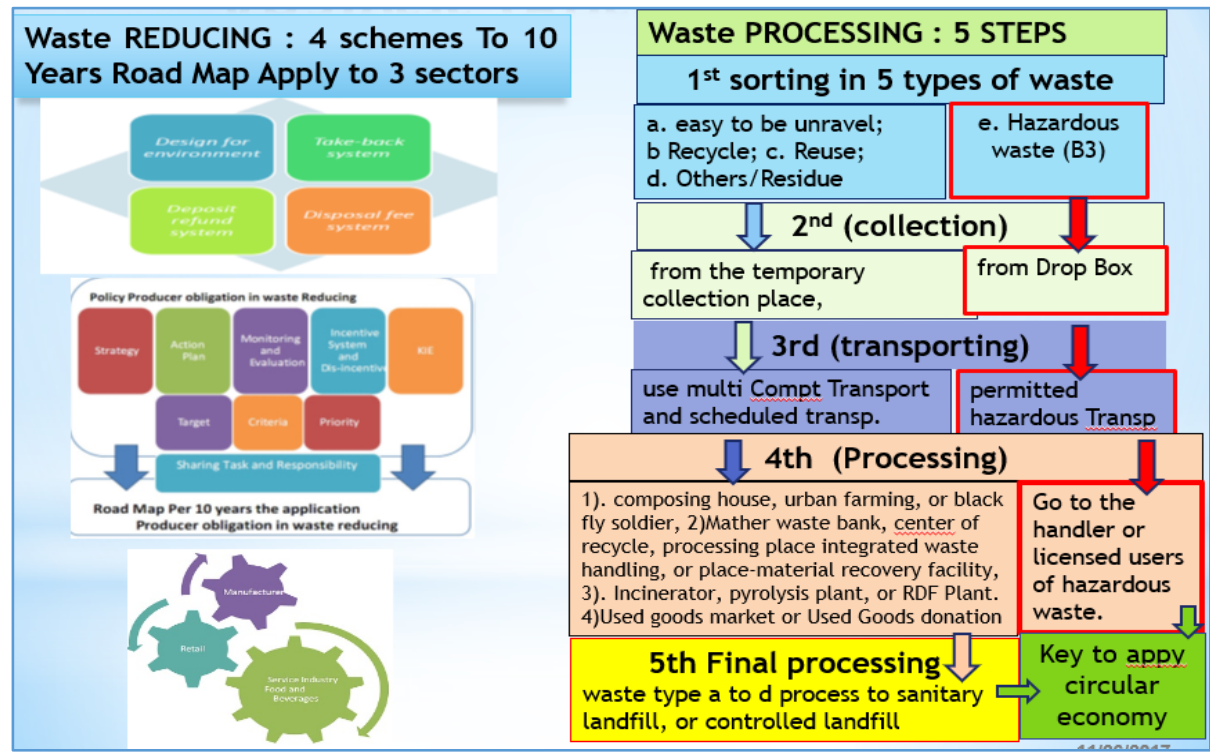

Figure 2. Two Types of Waste Management in Airport

The implementation scheme of producer's obligation for $1^{\text {st }}$ type (Waste reducing) there are 4 schemes are: a. Design for environment; b. Take back system; c. Deposit refund system, and; d. Deposit fee system. From those four schemes, the policy of Producers obligation in reducing waste divided into 8 policies 1). Strategy; 2). Action plan; 3). Monitoring and evaluation; 4). Incentive and disincentive system; 5) Campaign, informing and educating (KIE); 6). Target; 7). Criteria and; 8). Priority. We then considered all policies in dividing task and responsibility, and finally become a Road map for 10 years implementation of the producer's obligation for reducing the waste. This Road map purpose for 3 sectors of producer group, a). Retail; b). Manufacture and; c). Food and beverage service industry. For the $2^{\text {nd }}$ type (Waste Processing) there are 5 step 
processes, starting from $1^{\text {st }}$ step is waste sorting into 5 types of waste a. easy to be unravel; b Recycle; c. Reuse; d. Others/Residue and; e. Hazardous waste (B3). $2^{\text {nd }}$ step waste collection four of them into two areas, for types a to $\mathrm{d}$ from the temporary collection place, while for type e. Hazardous waste from Drop Box (especially for hazardous waste). $3^{\text {rd }}$ step the waste transportation will use multi compartment transportation and scheduled transportation on waste type basis for waste type a to $d$, while for waste type e will use permitted especial hazardous transportation. $4^{\text {th }}$ step the waste processing, for a to d prepare four medias to process it, 1). Go to composing house, urban farming, or black fly soldier, 2). Go to Mather waste bank, center of recycle, processing place-integrated waste handling, or place-material recovery facility, 3). Go to incinerator, pyrolysis plant, or RDF Plant. 4) Go to Used goods market or Used Goods donation, while for; 5). Go to the handler or licensed users of hazardous waste. $5^{\text {th }}$ step is the final waste processing when waste type a to d process to sanitary landfill, or controlled landfill, then process to Methane gas utilize facility for thermal usage or electricity usage. Further from both process above, The Airport regulator should create the modeling of waste management refer to Indonesian Law Number : UU 18/2008 and its sub law of Ministerial Decree of Communication of The Republic Indonesia Number: PM 54 year 2017. The other national law also support this waste management is Indonesian Law UU $23 / 1992$ about Healthy (Indonesia, 1992) $5^{\text {th }}$ part of health of environment Chapter 22, consist of five verses ${ }^{(1)}$ Health of environment is held to have health environment quality, ${ }^{(2)}$ Health of environment implement at public area, housing, work environment, and other environment, (3) Health of environment cover water and air purification, safe the solid, aqueous and gas waste, radiation and sound effect, disease vector control, and healthy or other safety, ${ }^{(4)}$ Every place or public service area must maintain and increase health environment based on the standard and requirement, ${ }^{(5)}$ The Provision about arranging the health environment has been explained on verses ${ }^{(1)}$ to ${ }^{(4)}$ has been legalized on Government regulation (PP). Based on the above model, so the producer has 
two efforts either on 1. the source by reducing effort and; 2. the aspect of handling the activity of airport for domestic and international flight. For source 1(reducing effort), there are two activities. a. source from airport activity operation - by campaign, information, and education / KIE, at 1). Offices, by green office program; 2). Tenant, by Green procurement; 3) Clean yard and airport park areas; 4) For passenger and visitor, and b. source from Aircraft operation, by using utensils repeatedly, select the recyclable food and beverage packaging, and less packaging for food and beverages, product served/sole. For source 2 the aspect of handling the activity of airport for domestic and international flight. a. domestic flight, Airport operator need to campaign, inform and educate public by sorting waste into 5 bins provided, collecting to TPS and TPS 3R, processing by composting, compos home, waste press machine, waste cutting machine, bio digester, incinerator, and $3 \mathrm{R}$, transporting waste by multi compartment waste truck and arrange the schedule on waste type basis, finally monitoring and evaluation by recording, weighing and measuring; $b$. International flight, Airport operator need to campaign, inform, and educate public by collecting to a special bin and special TPS, processing by using incinerator and ; transporting by waste residue truck. The function of public policy and the process implementation will not work properly without the presence of Airport regulator who do the supervisory for the process. Cause on the implementing regulation, there is an obligation of every airport operator in waste management by a) Appoint unit or personnel who responsible to manage waste and chemical; b) Set up the procedure of managing waste and chemical; c) Execute to manage waste and chemical which is resulted from airport and aircraft; d) Supervise stake holder on aviation who has the waste and chemical in airport and do the waste and chemical management. e) Cooperate and/or has agreement related to the waste and chemical management with stake holder in airport; and f) Report the execution of waste and chemical management to Directorate General and Head of Airport Authority once every six months. 


\section{Discussion}

From the FGD we found that $1^{\text {st }}$. the waste keeping ideally has the longest period as follow, for the first 90 days is $50 \mathrm{~kg} / \mathrm{day}$, the for the $2^{\text {nd }}$ 180 days, less than $50 \mathrm{~kg} / \mathrm{day}$, and the $3^{\text {rd }}$ is 365 days also less than 50 $\mathrm{kg}$ /day. this to minimize the risk, as well as implement the proper waste \& chemical management. $2^{\text {nd }}$. Hand over to the Regional Government (PEMDA) from Airport Operator when waste has been moved to TPS and TPA, and this hand over must be covered by proper agreement, while when the waste still in location or airport, become fully responsible of Airport operator. "While during transportation if there is an accident or negative impact of this process, will become responsibility of regional government or appointed handling party. Because the waste management in airport was categorized as household waste" (Bovea, Ibáñez-Forés, Gallardo, \& Colomer-Mendoza, 2010) its model of household waste collection is based on a combination of the selective collection of glass, paper/ cardboard and packaging at materials banks and street-side collection of the rest waste, therefore no specific permit needed, however if any hazardous waste resulted so must follow the current regulation related to the handling of hazardous waste. The matter of incinerator utilization, has two dilemmas, where $1^{\text {st }}$ the fuel (solar) that become high and $2^{\text {nd }}$ the efficiency side.

Finally, the report form of reporting and hazardous waste management must be agreed in advance. $3^{\text {rd }}$ Create the Technical instruction based on the public policy that comes from international, regional, national, and local regulation to have integrated waste management for stake holder concerned. Starting from the Ministerial Decree of Communication Number: PM $54 / 2017$ cause this decree has covered all the aspect of waste management in eleven chapter. The FGD discussion by stake holders on the waste management socialization also means and conclude that $1^{\text {st }}$ there must be technical instruction as sub regulation to manage properly the waste management system in airport, therefore all stake holder can refer to one guidance with same perception in the future. $2^{\text {nd }}$ For the stake holder, the airline, ground handling also the custom as the counterpart of the aircraft 
and warehouse operator, those parties must aware for hazardous material resulted from carrying dangerous goods into Soekarno-Hatta Airport and they must dispose the dangerous goods within certain safety time, in order to avoid hazardous waste stacking inside the public area and endanger all the environment. "Each delivery should obey certain rules and regulations made by the government in order to avoid chaos"(Azhar \& Rizaldy, 2015). The utilization of warehouse in Soekarno-Hatta Airport in 2014 is 64\%, which includes in the level of over utilized. Meanwhile the utilization prediction in 2015 will be $75 \%$. The warehouse utilization forecast in 2019 will be $139 \%$. This condition will be over utilized, will be over flow (Ricardianto \& Rifni, 2016) The Airport Operator should conduct further the proper disposal of hazardous waste management in airport by next review with certain methodology to ensure that they use better handling. We realized that this review paper will not perfectly explain and solve all the waste management matter in Soekarno-Hatta Airport, however we try as objective as we can to gather all the data to recover the obstacle. Due to the socialization of this Minister decree PM54/2017 may take time to analyze whether the Airport Regulator can create the technical instruction from this national law and implemented properly as per suggestion and recommendation from the International Law, Indonesian Government Laws and best practice of practitioners from other country. Benefit of the stake holder in airport to have the Standard Operating Procedure (SOP) as a assisting tool for implementing the integrated waste management while waiting the technical instruction from Airport Regulator, the SOP based on this Minister decree /PM54 will give advantage for each stake holder as handling guidance for staff to maintain healthy, environment health and finally can apply it to handle the waste at the other airport in Indonesia beside Soekarno-Hatta Airport. Recommendation for stake holder especially the tenant in airport area to adjust the SOP as well with the local condition of the airport. Then to Simplify the process and large of facilities depend on the waste volume and quantity produce by each producer in airport. 


\section{References}

Azhar, F., \& Rizaldy, W. (2015). Strategies in Enhancing the Qualityservices of Traffic Special. Jurnal Manajemen Bisnis Transportasi Dan Logistik, 82-91.

Bovea, M. D., Ibáñez-Forés, V., Gallardo, A., \& Colomer-Mendoza, F. J. (2010). Environmental assessment of alternative municipal solid waste management strategies. A Spanish case study. Waste Management, 30(11), 2383-2395. https://doi.org/10.1016/j.wasman.2010.03.001

Curkovic, S., \& Sroufe, R. (2011). Using ISO 14001 to promote a sustainable supply chain strategy. Business Strategy and the Environment, 20(2), 71-93. https://doi.org/10.1002/bse.671

Indonesia, P. R. (1992). Undang Undang No . 23 Tahun 1992 Tentang: Kesehatan. Undang Undang No. 23 Tahun 1992 Tentang: Kesehatan, (23), 1-31.

Juliater Simarmata, Charles, \& Rizaldy, W. (2014). The Impact of Fuel Increase and Currency Exchange Depreciation on Indonesia Aviation Industry Sustainability. Jurnal Manajemen Transportasi \& Logistik (JMTransLog) $\quad$-, 1(3), 199-208. https://doi.org///dx.doi.org/10.25292/j.mtl.v1i3.18

Kania, D. D. (2016). Analisis Faktor Budaya Keselamatan dan Kesehatan Kerja ( K3 ) Pada Penanganan Kargo Di Bandara Soekarno Hatta International Airport. Jurnal Manajemen Transportasi \& Logistik, 3(1), $1-13$.

MacDonald, J. P. (2005). Strategic sustainable development using the ISO 14001 Standard. Journal of Cleaner Production, 13(6), 631-643. https://doi.org/10.1016/j.jclepro.2003.06.001

Pitt, M., Brown, A., \& Smith, A. (2002). Waste management at airports. Facilities, 20(5/6), 198-207. https://doi.org/10.1108/02632770210426684

Potoski, M., \& Prakash, A. (2005). Covenants with weak swords: ISO 14001 and facilities' environmental performance. Journal of Policy Analysis and Management. https://doi.org/10.1002/pam.20136

Ricardianto, R. P., \& Rifni, M. (2016). Air Cargo Capacity on Cargo Terminal Development Plan at Soekarno-Hatta International Airport. Jurnal Manajemen Transportasi \& Logistik (JMTRanslog), 1(2).

S, T. I. H. (2016). Multimoda Dalam Mewujudkan Visi Logistik Indonesia 2025. Jurnal Manajemen Transportasi \& Logistik (JMTRanslog), 3(1), 69-84.

Seadon, J. K. (2006). Integrated waste management . Waste Management, 26, 1327-1336. https://doi.org/10.1016/j.wasman.2006.04.009

Setiyono. (2001). Dasar Hukum Pengelolaan Limbah B3. Jurnal Teknologi Lingkungan, 2(1), 72-77. Retrieved from https://www.google.co.id/url?sa=t\&rct=j\&q=\&esrc=s\&source=web\&c $\mathrm{d}=1 \& \mathrm{cad}=\mathrm{rja} \& u a c t=8 \& \mathrm{ved}=0 \mathrm{ahUKEwjSne}-\mathrm{OmMjUAhXJNY8KHU} 2$ ZBlcQFggjMAA\&url=http\%3A\%2F\%2Fejurnal.bppt.go.id\%2Fejurnal 2011\%2Findex.php\%2FJTL\%2Farticle\%2Fview\%2F214\&usg=AFQjC NH7tlnFZoBG8Sp18N1U93C2LaV5qg 
Sin, T. J., Chen, G. K., Long, K. S., Goh, I., \& Hwang, H. (2013). Current practice of waste management system in Malaysia: Towards sustainable waste management. In: 1st FPTP Postgraduate Seminar "Towards Sustainable Management," 1106, 1-19. https://doi.org/10.18517/ijaseit.2.2.169

Ta, G. C., Jonai, H., Mokhtar, M. Bin, \& Peterson, P. J. (2009). Model for the implementation of the globally harmonized system of classification and labelling of chemicals (GHS): Lessons learned from Japan. Journal of Occupational Health, 51(6), 526-530. https://doi.org/10.1539/joh.P9001

Ujang, Z. (2000). Case Study: Hazardous waste management in malaysia. Hazardous Waste Management in Malaysia, 1952(Focuses on hazardous waste management in Malaysia, a country undergoing a rapid process of urbanization and industrialization), 4.

United Nations. (2015). Globally Harmonized System of Classification and Labelling of Chemicals (GHS) (Rev.6) (2015). Regulation. https://doi.org/10.1265/jjh.65.5 